\title{
Laser angioplastyに関する実験的研究
}

- laser照射部の血管壁の経時的変化を中心に一 Experimental Studies on Laser Angioplasty; the healing process in canine arteries after transluminal laser irradiation

\author{
辻義彦、岡田昌義、吉田正人、中村和夫 \\ Yoshihiko Tsuji, Masayoshi Okada, Masato Yoshida \\ Kazuo Nakamura
}

神戸大学第二外科

With argon laser coupled to a fiberoptic system, experimental studies were carried out to evaluate the healing response of the normal arteries to laser irradiation. Firstly, the femoral and carotid arteries in the canine were exposed, and laser irradiation of argon was delivered transluminally by bare ended probe with angioscope by which acute intravascular laser effects were observed. Between 24 hours and 10 weeks after these procedures, the lased canines were anesthetized again, and the healing process of the lased arterial wall was evaluated angioscopically. Subsequently, deep craters covered with char were observed 24 hours after lasing, and fresh thrombus was recognized on the crater in only one of 12 cases. One week after lasing, craters become shallow, and the color of arterial wall around the craters changed reddish by subintimal hematoma. By two weeks, progression of the healing process was observed macroscopically. That is, craters were covered with endothelium and decrease of reddish color of arterial wall around the craters was clearly noted endoscopica11y. Almost all craters were completely reendothelialized until four weeks after lasing, and the lased areas were completely healed after 10 weeks, angioscopic findings above mentioned were proved pathologically. In conclusion, it could be considered that healing process of the lased arterial wall was completely achieved by four weeks after laser irradiation and angioscopy was useful procedure to observe intravascular laser effects. 
今回我々はArgon laserを用いてlaser照射部の 血管壁の治瘠過程を内視鏡的並びに組織学的に検 討した結果、 2 〜の知見を得たので報告する。 方法: Argon laser sourceとしてendocoagulator model 20(hgm社製) を用い, bare ended probeを 使用して動脈壁にlaserを照射した。すなわち、 全身麻酔下に杂隹種成犬（10１5kg）の大腿動脈及 び頸動脈を露出し、これに切開を加えてlaser probeを㨂入した。1〜2W、1〜2秒のlaser照 射を流血中にて行い、その後血管内視鏡(01 ympus 社製、2.5mm)を用いてlaser照射部を観察した。 この後、動脈切開部は $7-0$ prolene糸にて縫合 閉鎖し、末梢動脈の拍動の良好なことを確認して 閉創した。一方、抗凝固療法としてはこの操作前 にheparin(100 units $/ \mathrm{kg})$ を全身投与するに留ど めた。かかる手技より24時間、1 週間、2 週間、 4 週間、10週間目に再度麻酔下にlaser照射部の 血管壁の治㽷の程度を内視鏡学的に観察し、その 後摘出して病理組織学的に検討した。なお、6群 の期間において各々 12柾例、計72出:例のlaser照 射部位を観察、検討した（表 1)。

研究成績 :

（1）Laser照射直後の血管壁の反応

Laser probeの先端を血管壁に接触させて照射 したところ、表面に炭化物を伴うcraterの形成が みられ、時に3〜4 Joulesटいう低いlaser energyの照射にも拘わらず動脈穿孔の発生する場合 があった。その内視鏡所見及び肉眼所見を図 1 に 示すが、laser照射部分には直径 $1 \mathrm{~mm}$ 大のcrater が形成されており、その表面には炭化物や血液凝 固物が付着していた。病理組織所見ではcrater表 面には凝固壊死層か柋められ、中膜内層では平滑 筋の細胞核の消失や間質の浮腫が軽度に認められ た。

（2）Laser照射部の治療過程

動脈壁にlaser照射を行ってその後24時間から

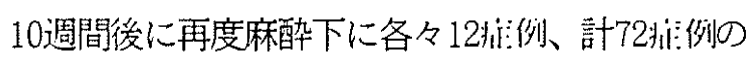
laser照射部を内視鏡下に詳細に観察したが、血 栓により閉塞した例は認められなかった。

Laser照射後24時間経過した例の内視鏡所見を みると、craterの形や性状は照射直後とほとんど 变化はみられなかったが（図 2、左）、12例中た
表1. Laser照射部の観察期間と照射例数

\begin{tabular}{cc} 
観察期間 & Laser照射例数 \\
\hline 直後 & 12 \\
24時間 & 12 \\
1 週間 & 12 \\
2 週間 & 12 \\
4 週間 & 12 \\
10週間 & 12 \\
\hline
\end{tabular}

72
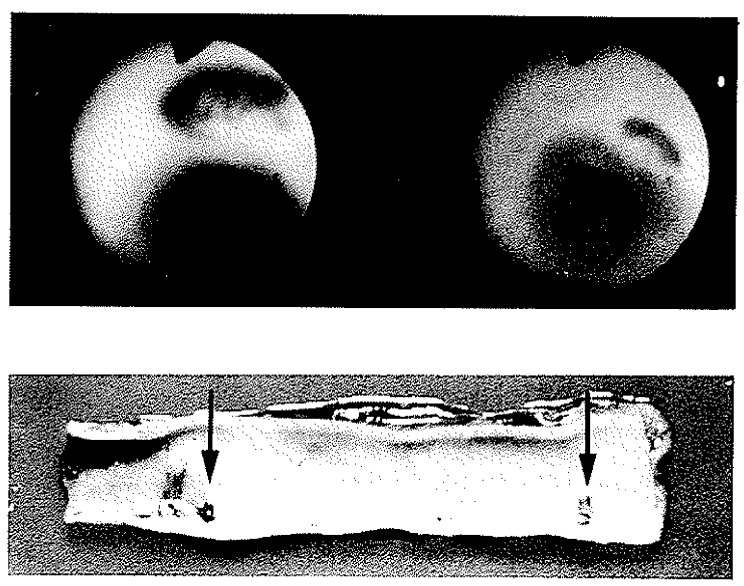

図1. Laser照射直後の所見 （上）内視鏡所見（下）肉眼的所見
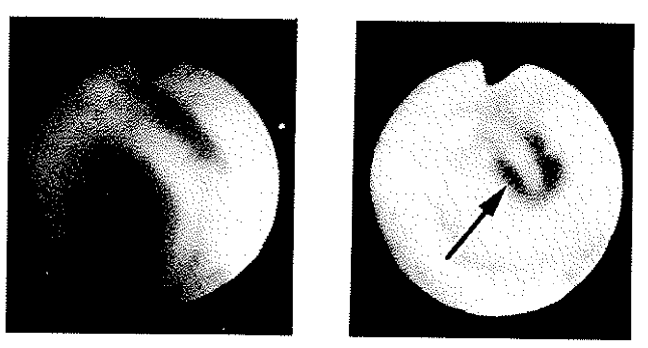

図2. Laser照射24時間後の内視鏡所見 
だ1例のみにcrater表面に付着する新鮮な小血栓 の存在が認妨れた（図2、右）。

Laser照射後 1 週間経過した例ではcrater表面 の炭化物の付着はわずかに認められるのみであり、 さらにcraterも浅くなっている現象か確認された

（図3、左）。ところが、crater周囲には発赤が みられ、壁内出血または炎症の存在が疑われた

（図 3、右）。これを病理組織学的に検索すると、 laser照射部周囲の中膜間質に軽度の出血巣力認 められたが、炎症反応はほとん亡゙認められなかっ た。このように、肉眼的にみられた発赤部分は壁 内出血であることが判明した（図 4)。

次に、laser照射後 2 週間経過した例を内視鏡 並びに肉眼的に観察したところ、crater周囲には 発赤は残存していたか消退傾向にあり、肉眼的に はcraterの表面には炭化物や凝血塊の付着は認め られず、むしろ内膜化され、craterは浅くなって いる所見か認められた（図5）。

さらにlaser照射後 4 週間経過した例ではcrater周团の発赤はわずかとなり、crater表面は完 全に内膜化されており、かなり修復過程が進んで いる所見か確認された。 Laser照射10週間経過後 ではcrater周囲の発赤は全く消失し、craterは血 管壁の小さなくぼみとしてのみ観察された（図6） この部を病理組織学的にみるとlaser照射部は周 囲より内膜が増生し、一層の内皮細胞で被覆され 治瘺しており、通常の創傷治瘾期間より早いこと か確認された。又、照射直後核の消失がみられた 中膜の平滑筋細胞の増生もみられ、血管壁の構築 は完全に再生されていた（図７）。

一方、metal tip probeを用いた場合について も同様に検討を加えた。すなわち $6 \mathrm{~W} 、 3 〜 5$ 秒 のlaser energyにて流血中で血管壁を焼灼したと ころ、輪状に白色化したthermal injuryの発生が 認められ、特に $6 \mathrm{~W} 、 4$ 秒以上のlaser energyで は血管壁にうす茶色の焼灼跡が認められた(図8)。 thermal injury部では血管壁が薄くなり、同部を 中心に血管壁の収縮する傾向がみられた。しかし、 内膜のけばだちや炭化物の付着は少なく、また長 期間にわたる観察においても血栓の付着などは認 めなかった。

考察：Laser照射後の血管壁の治療過程について

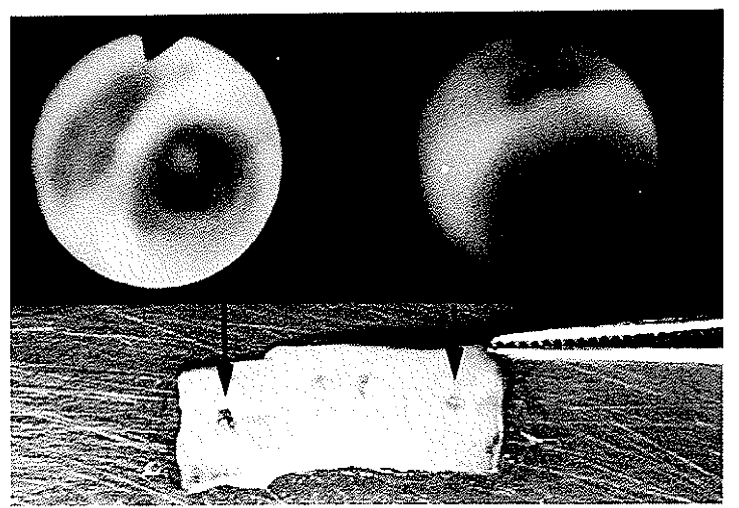

図3. Laser照射 1 週間後の所見

（上）内視鏡所見（下）肉眼的所見

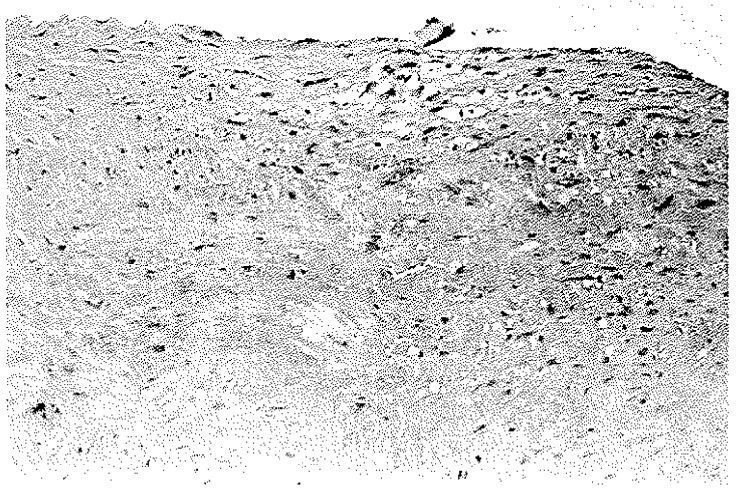

図 4. Laser照射 1 週間後の病理組織学所見
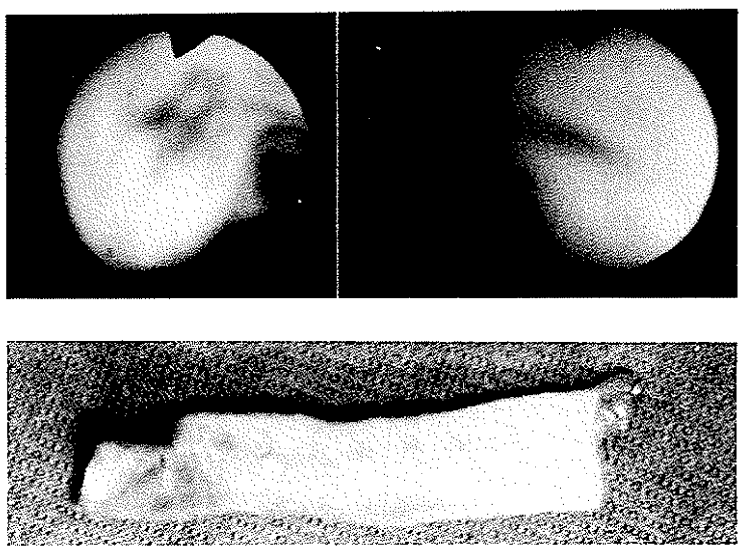

図5. Laser照射 2 週間後の所見

（上）内視鏡所見（下）肉眼的所見 

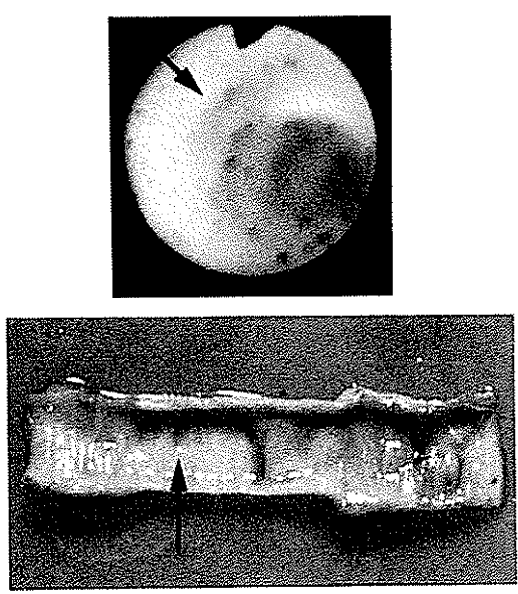

図6. Laser照射10週間後の所見

（上）内視鏡所見（下）肉眼的所見

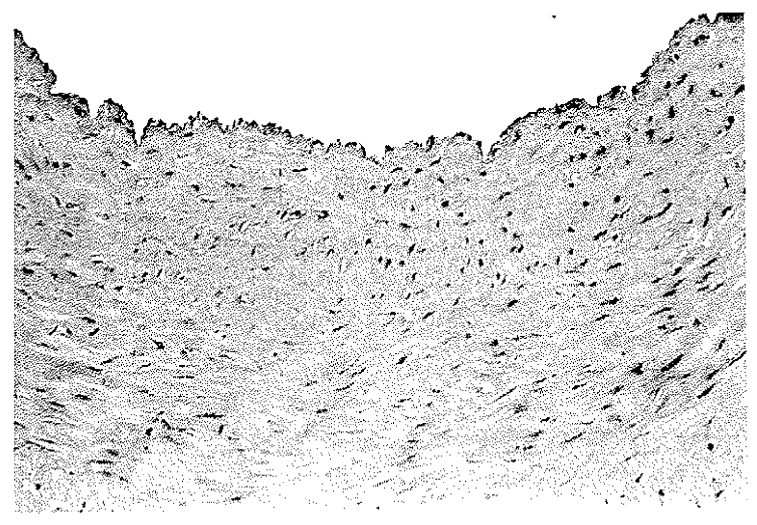

図7. Laser照射10週間後の病理組織学所見
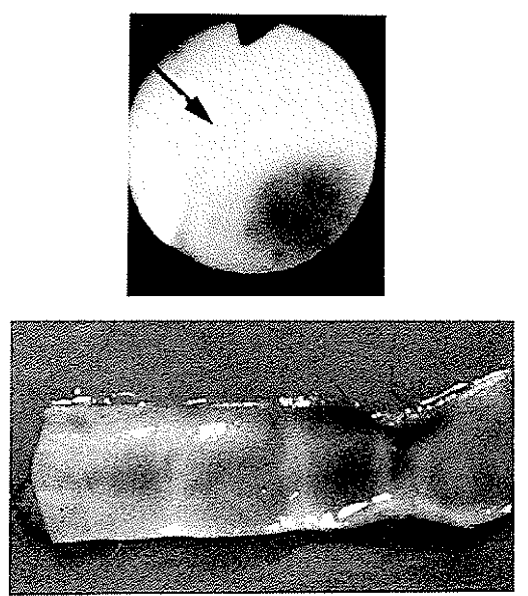

図8. Metal tip probe使用でのLaser照射直後の 所見

（上）内視鏡所見（下）肉眼的所見
は現在までに数例の報告はミ3゙か潵見されるのみ である。

今回我々はlaser照射部の組織学的所見亡内視鏡 所見莸対比し、内視鏡の有用性について検討した。

1. Laser出力之照射時間

Bare ended probeを使用して出力 $1 \sim 2 W$ 、照 射時間 1 〜2秒、metal tip probeを使用して出 力 $6 \mathrm{~W}$ 、照射時間 3〜5秒としたが、これは動脈 壁に対する基礎的研究》のにもとずいて決定した。

2. Laser照射後の血管壁の治瘾過程

2〜4 週間後にはlaser照射部は表面が内膜化 されたcraterとして認められるようになり、さら に10週間後には血管壁の構築も完全に再生された。 一般的に創傷治㾍には少なくとも 3 力月が必要で あることから考えて、かなり短期間に治癒したと 考えら机、かかる早期の治癒機転を考慮すると laserによるangioplastyは優れた手段であること か沶唆された。

\section{Laser angioplasty後の抗凝固療法}

Bare ended probeを用いた際に12例中わずか 1 例ではあるが24時間後にlaser照射部に新鮮血栓 の付着する所見がみられた事実から、ang ioplasty 後には抗凝固療法の必要性が呈示された。

4. Laser probeによる対比

Bare ended probecmetal tip probeを対比し たところ、後者では焼灼部のけばだちや炭化物の 付着は軽微であり問題とならなかった。しかし健 常な血管壁は熱により収縮する傾向が呈示され、 血管の太さにみあった径のprobeの使用か肝要で あること、及び健常な血管壁には可及的接触させ ないよう留意することが必要であると考えられた。 まとめ：（1）血管内laser照射にて閉塞の発生 はみられず、laser照射部は 2〜 4 週間で内膜化 された。（2）血管内視鏡所見は組織所見とよい 相関を示し、laser照射部の内視鏡による観察は 有用であった。

文献:

1)Abela GS et al. :Am J Cardiol(56)983, 1985

2)Sanborn TA et al. :Circulation(75)1281, 1987

3)Gerrity RG at al. : J Thorac Cardiovasc Surg (85) 409,1983

4) 岡田、过他:日本レーザー医学会誌8(3)5、1987

5)辻、岡田他:日本レーザー医学会誌8(3)153、1987 